\title{
Identification of human thioredoxin as a novel IFN-gamma-induced factor: Mechanism of induction and its role in cytokine production Seol-Hee Kim ${ }^{\dagger}$, Jiyoung $\mathrm{Oh}^{\dagger}$, Ja-Young Choi, Ji-Young Jang, Myoung- Wha Kang and Choong-Eun Lee*
}

Address: Laboratory of Immunology, Department of Biological Science, Sungkyunkwan University, Suwon 440-746 Korea

Email: Seol-Hee Kim - aprilseol@skku.edu; Jiyoung Oh - jyoh540@skku.edu; Ja-Young Choi - mountainwhite@hanmail.net; JiYoung Jang - jjy93@hanmail.net; Myoung-Wha Kang - splicing@empal.com; Choong-Eun Lee* - celee@skku.edu

* Corresponding author †Equal contributors

Published: 5 November 2008

BMC Immunology 2008, 9:64 doi:10.1 |86/|47|-2172-9-64
Received: 15 March 2008

Accepted: 5 November 2008

This article is available from: http://www.biomedcentral.com/I47I-2/72/9/64

(c) 2008 Kim et al; licensee BioMed Central Ltd.

This is an Open Access article distributed under the terms of the Creative Commons Attribution License (http://creativecommons.org/licenses/by/2.0), which permits unrestricted use, distribution, and reproduction in any medium, provided the original work is properly cited.

\begin{abstract}
Background: IFN- $\gamma$ is a multifunctional peptide with a potent immune defense function which is also known as a prototypic ThI cytokine. While screening for genes differentially expressed by ThI and Th2 cytokines, human thioredoxin was identified as a novel target gene induced by IFN- $\gamma$. The mechanism by which thioredoxin is induced by IFN- $\gamma$ and the signaling pathways involved in its induction were analyzed. In addition, the effects of thioredoxin on immune cell survival and cytokine production were examined by thioredoxin over-expression and recombinant thioredoxin treatment.

Results: Human thioredoxin was selectively induced by IFN- $\gamma$ in monocytic and $\mathrm{T}$ cell lines. In monocytic cells, the induction of thioredoxin gene expression by IFN- $\gamma$ was dose-dependent, and both the mRNA and protein levels were increased by $2 \sim 3$ fold within 4 to $24 \mathrm{~h}$ hours of IFN- $\gamma$ treatment. The thioredoxin induction by IFN- $\gamma$ was insensitive to cycloheximide treatment, suggesting that it is a primary response gene induced by IFN- $\gamma$. Subsequent analysis of the signaling pathways indicated that the Jak/Stat, Akt, and Erk pathways play a role in IFN- $\gamma$ signaling that leads to thioredoxin gene expression. Thioredoxin was induced by oxidative or radiation stresses, and it protected the immune cells from apoptosis by reducing the levels of reactive oxygen species. Furthermore, thioredoxin modulated the oxidant-induced cytokine balance toward ThI by counter-regulating the production of IL-4 and IFN- $\gamma$ in T cells.
\end{abstract}

Conclusion: These data suggest that thioredoxin is an IFN- $\gamma$-induced factor that may play a role in developing ThI immunity and in the maintenance of immune homeostasis upon infection, radiation, and oxidative stress.

\section{Background}

IFN- $\gamma$ is a pleiotropic cytokine with a broad range of antiviral and immuno-modulatory actions. It is induced by various immune triggers and plays a critical role in directing cellular immune responses and inflammation against infection caused by intracellular pathogens such as viruses and certain bacteria to function as a Th1 type cytokine [13]. In addition, IFN- $\gamma$ also regulates cell growth affecting differentiation, survival, and apoptosis in a wide range of cell types [4]. These actions of IFN- $\gamma$ are shown to be 
mediated by a large number of IFN- $\gamma$-induced specific gene products which include interferon regulatory factors $[5,6]$, antiviral factors [7-9], chemokines $[10,11]$, cytokine receptors [12], signaling molecules $[13,14]$, and apoptosis-regulatory factors $[15,16]$. As a part of our ongoing investigation of the mechanisms involved in regulation of the Th1 and Th2 immune response, we screened for novel target genes whose expressions are differentially regulated by Th 1 and Th 2 cytokines by performing differential display-polymerase chain reaction (DD-PCR) analysis with human peripheral blood mononuclear cells (PBMCs). From such analysis human thioredoxin (Trx-1) was identified as a novel target specifically induced by IFN- $\gamma$.

Mammalian thioredoxins are a family of proteins that contain a conserved -Trp-Cys-Gly-Pro-Cys-Lys- catalytic site. When combined with glutathione, thioredoxins constitute a major group of redox proteins responsible for the regulation of intracellular redox status $[17,18]$. During the redox regulation, thioredoxin undergoes reversible oxidation/reduction of the two cysteine groups. The dithiol($\mathrm{SH})$ form of thioredoxin reduces oxidized protein substrates that contain a disulfide group, and the oxidized form then cycles back in an NADPH-dependent process that is mediated by thioredoxin reductase, another protein that contains a thiol group $[19,20]$. Thioredoxin is released from the cell in a redox-sensitive manner, and the serum thioredoxin level is considered to be an indicator of oxidative stress, especially in cases of liver diseases $[21,22]$.

It was initially reported that human thioredoxin stimulated the growth of transformed $\mathrm{T}$ and $\mathrm{B}$ cell lines $[23,24]$. Since then, it has been suggested that thioredoxin has both apoptotic and survival functions in diverse cell systems [25]. Recently, studies evaluating the anti-apoptotic effect of thioredoxin have indicated that thioredoxin, through its redox-control functions, affects cell growth and survival by perturbation of specific apoptosis signaling molecules, such as apoptosis-stimulating kinase-1 $[26,27]$. In addition, it has been reported that truncated thioredoxin (Trx80) stimulates monocytes/macrophages to induce IL-12, implying that it is involved in immuneinflammatory reactions that direct Th1 immunity and IFN- $\gamma$ production [28].

In light of these findings which suggest that thioredoxin functions in the regulation of immune cell growth and possibly in Th1 immune response, it was interesting for us to identify thioredoxin as a novel target induced by IFN- $\gamma$ in cells of immunological origin. Therefore, we examined the mechanism by which IFN- $\gamma$ induces and regulates thioredoxin gene expression. In addition, we evaluated the role that thioredoxin plays in immune cell survival and cytokine production upon oxidative stress. The results of this study shed light on the coordinated immune defense function of IFN- $\gamma$ and thioredoxin during diverse stress responses to infection and apoptotic stimuli.

\section{Results}

\section{Identification of thioredoxin as a novel target induced by IFN- $\gamma$}

During DD-PCR screening for novel factors involved in the modulation of Th1 and Th2 immune response, we identified a number of target genes that were differentially regulated by Th 1 and Th2 cytokines [29,30]. In particular, by screening mRNAs isolated from human PBMCs stimulated with IL- 4 and/or IFN- $\gamma$ by DD-PCR, Clone A1 was first noted as a product selectively induced upon stimulation by IL- 4 and IFN- $\gamma$, but not by IL- 4 alone, indicating that it is an IFN- $\gamma$-induced factor. By using Clone A1 as a probe on a Northern blot analysis of human PBMCs, a specific induction by IFN- $\gamma$ of a single mRNA species with 550 bases was detected (see Additional file 1). Subsequent cloning and sequence analysis revealed that Clone A1 contained part of the 3' coding and the 3'UTR sequence of human thioredoxin as in MGC:5174 (Genebank accession \# $\mathrm{BC003377}$ ). Subsequently, screening of Jurkat $\mathrm{T}$ cell cDNA expression libraries using the Clone A1 probe and the RT-PCR cloning produced a clone of full-length thioredoxin cDNA that was comprised of 530 bases coding 105 amino acids, including the conserved 31Trp-CysGly-Pro-Cys35 motif (see Additional file 1) which was identical to the previously reported sequence of human thioredoxin [31].

\section{Regulation of thioredoxin gene expression by IFN- $\gamma$ in immune cells}

Using a full-length cDNA probe for thioredoxin, the induction and regulation of human thioredoxin gene expression by IFN- $\gamma$ was examined in various immune cells. Northern blot analysis revealed that IFN- $\gamma$ significantly up-regulated the thioredoxin mRNA levels in THP1 monocytic cell line and Jurkat $\mathrm{T}$ cell line, although the upregulation was less significant in Jurkat cells. Conversely, IL-4, a prototypic Th2 cytokine, did not have an inducing effect on the thioredoxin mRNA levels in these cells (Fig 1A-a, b). RT-PCR analysis also revealed a similar regulation pattern of thioredoxin gene expression in IFN- $\gamma$ - or IL-4-treated THP1 and Jurkat cells. (see Additional file 2). The thioredoxin-inducing effect of IFN- $\gamma$ was also seen in Ramos B cells and human PBMCs [32]. Taken together, these data indicate that the induction of thioredoxin gene expression by IFN- $\gamma$ is common to various types of immune cells.

Prior studies evaluating human thioredoxin mRNA expression and regulation in immuno-competent cells have shown that, although the constitutive level of thioredoxin expression is relatively low in primary lymphocytes 
A

(a)

Thioredoxin

$\beta$-actin

\begin{tabular}{|c|c|c|c|c|}
\hline$\amalg-4$ & - & + & - & + \\
\hline IFN-y & - & - & + & + \\
\hline
\end{tabular}

(b) THP1 Monocytic cells

Thioredoxin

ק-actin

\begin{tabular}{|c|c|c|c|c|}
\hline $\mathbf{L}-\mathbf{4}$ & - & + & - & + \\
\hline $\mathbf{I} \mathrm{N}-\mathrm{y}$ & - & - & + & + \\
\hline
\end{tabular}

(c) THP1 Monocytic cells

\begin{tabular}{|c|c|c|c|c|}
\hline $\begin{array}{l}\text { redoxin } \\
\beta \text {-actin }\end{array}$ & te & & $=$ & $=$ \\
\hline IFN-Y & - & + & - & - \\
\hline IFN- $\alpha$ & - & - & + & - \\
\hline 匹-2 & - & - & - & + \\
\hline
\end{tabular}

B

(a) Jurkat $T$ cells

\begin{tabular}{|c|c|c|c|c|c|c|c|c|c|c|}
\hline Thioredoxin & -4 & $\because 6$ & $\therefore 4$ & $=0$ & 20 & 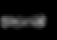 & ك & $\rightarrow$ & ك- & $\omega$ \\
\hline$\beta$-actin & 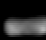 & so & - & 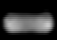 & 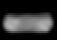 & 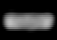 & 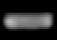 & $\Leftrightarrow$ & 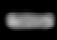 & $=$ \\
\hline Time (h) & & & 2 & & & & & 24 & & \\
\hline IFN-Y & - & + & - & - & - & - & + & - & - & - \\
\hline LPS & - & - & + & - & - & - & - & + & - & - \\
\hline PMA & - & - & - & + & - & - & - & - & + & - \\
\hline PHA & - & - & - & - & + & - & - & - & - & + \\
\hline
\end{tabular}

(b) THP1 Monocytic cells

\begin{tabular}{|c|c|c|c|c|c|c|c|}
\hline Thioredoxin & & $\longrightarrow$ & - & 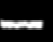 & $m$ & $\cdots$ & \\
\hline$\beta$-actin & E & 0 & a & $\theta$ & 0 & 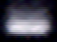 & 0 \\
\hline IFN-y & - & + & + & - & - & - & - \\
\hline LPS & - & - & - & + & + & - & - \\
\hline PHA & - & - & - & - & - & + & + \\
\hline$\alpha-[F N-y \quad A b$ & - & - & + & - & + & - & + \\
\hline
\end{tabular}

Figure I

Regulation of thioredoxin gene expression in immune cell lines. A. Regulation of thioredoxin gene expression by cytokines in immune cell lines. Human lymphocytic T cell line, Jurkat (Panel a) and the promonocytic cell line, THPI (Panels b and c), were maintained in complete RPMI media. Cells $\left(5 \times 10^{6}\right)$ were then treated with various cytokines $(10 \mathrm{ng} /$ $\mathrm{ml} \mathrm{IFN}-\gamma, 10 \mathrm{ng} / \mathrm{ml} \mathrm{IL-4,} 10000 \mathrm{u} / \mathrm{ml} \mathrm{IFN}-\alpha$, and $10 \mathrm{ng} / \mathrm{ml} \mathrm{IL-2}$ ) as indicated for $24 \mathrm{~h}$. The total RNA was then isolated and analyzed by Northern blot using a full-length cDNA probe of human thioredoxin. The membranes were stripped and reprobed for $\beta$-actin as an internal control. B. Effect of IFN- $\gamma$ and mitogens on thioredoxin gene expression. Panel a: Jurkat T cells $\left(2 \times 10^{6}\right)$ were treated with IFN- $\gamma(10 \mathrm{ng} / \mathrm{ml})$, LPS $(I \mu \mathrm{g} / \mathrm{ml})$, PMA $(10 \mathrm{ng} / \mathrm{ml})$ or PHA $(2.5 \mu \mathrm{g} / \mathrm{ml})$ in serum-free media for the indicated durations, after which RNAs were isolated and analyzed by RT-PCR using primers specific for thioredoxin. Panel $\mathbf{b}$ : THPI monocytic cells $\left(2 \times 10^{6}\right)$ were treated with IFN- $\gamma(10 \mathrm{ng} / \mathrm{ml})$, LPS $(\mathrm{I} \mu \mathrm{g} / \mathrm{ml})$, or PHA $(2.5 \mu \mathrm{g} / \mathrm{ml})$ in the presence or absence of anti-IFN- $\gamma$ Ab $(10 \mu \mathrm{g} / \mathrm{ml})$. The cells were then cultured for $24 \mathrm{~h}$, after which the total RNA was isolated and analyzed by RT-PCR using primers specific for thioredoxin and IFN- $\gamma$.

and monocytes, its level is significantly up-regulated in these cells upon activation by mitogens such as PMA, PHA, and LPS [31,33]. In fact, we observed the induction of thioredoxin by PMA, PHA, and LPS in Jurkat T cells and THP1 cells in this study (Fig 1B-a, b). However, the mechanisms by which thioredoxin induction occurs in response to these mitogens appear to differ, as indicated by the differential effects of anti-IFN- $\gamma$ antibodies on thioredoxin gene expression induced by LPS and PHA.
Specifically, treatment of cells with anti-IFN- $\gamma$ suppressed the thioredoxin-inducing effect of PHA, suggesting that PHA-induced thioredoxin expression is mediated by the action of IFN- $\gamma$ (Fig 1B-b).

While IFN- $\gamma$ induced prominent up-regulation of thioredoxin in monocytic cells, neither IL- 2 nor IFN- $\alpha$ had a significant enhancing effect on thioredoxin expression in these cells (Fig 1A-c). The up-regulation of thioredoxin by 
IFN- $\gamma$ observed in monocytic cells may have an important functional implication, since mononuclear phagocytes are the primary target of IFN- $\gamma$ during the immune and inflammatory responses that involve redox-regulatory mechanisms during the respiratory burst [34]. Therefore, we evaluated the mechanism by which thioredoxin induction by IFN- $\gamma$ occurred in monocytic cells using the THP1 cell line.

\section{Induction and regulation mechanism of thioredoxin expression by IFN- $\gamma$}

To confirm the specificity of thioredoxin gene regulation by IFN- $\gamma$, we examined the dose-dependency and kinetics of thioredoxin mRNA induction by IFN- $\gamma$. Treatment of THP1 cells with increasing doses of IFN- $\gamma$ from 1 to $20 \mathrm{ng} /$ $\mathrm{ml}$ resulted in up to a 2.7 fold increase in thioredoxin mRNA levels in a dose-dependent manner (Fig 2A). Furthermore, kinetic analysis of the thioredoxin mRNA induction revealed that, although the mRNA level gradually increases with time in response to IFN- $\gamma$ treatment both in the presence and absence of serum, a more prominent induction was noted under serum-starved conditions. The thioredoxin induction occurred within $4 \mathrm{~h}$ and significantly increased by $16 \mathrm{~h}$ post IFN- $\gamma$ treatment under serum-free conditions (Fig 2B, panels a and b). Moreover, this up-regulation of thioredoxin mRNA levels by IFN- $\gamma$ was not inhibited by the translational inhibitor, cycloheximide, which suggests that the IFN- $\gamma$-mediated induction of thioredoxin is a primary response which does not require on-going protein synthesis (Fig $2 \mathrm{~B}$, panel c). The induction of thioredoxin by IFN- $\gamma$ was also observed at the protein level which kinetically followed the induction of thioredoxin mRNA production. This increase in protein level began within $6 \mathrm{~h}$, and then gradually accumulated for $24 \mathrm{~h}$, ultimately increasing by the same magnitude (2.7 fold) as the mRNA (Fig 3). Taken together, these data indicate that IFN- $\gamma$ up-regulates the thioredoxin protein levels in monocytic cells through the induction of gene expression.

Because the up-regulation of thioredoxin gene expression appeared to occur as a direct response to IFN- $\gamma$ without involving on-going protein synthesis in IFN- $\gamma$-treated cells, we evaluated the initial signaling pathways involved in the IFN- $\gamma$-mediated induction of thioredoxin gene expression. The analysis of the signal pathways induced by IFN- $\gamma$ in monocytic cells revealed that, in addition to the well-known Jak1/Stat1 pathways [35], IFN- $\gamma$ generates strong activating signals for Akt, Erk and p38 MAPK within 15 to $60 \mathrm{~min}$ (Fig 4A). Treatment with inhibitors of Jak tyrosine kinases (AG490), PI3K/Akt (LY294002) and Erk (PD98059) suppressed the IFN- $\gamma$-induced effect on thioredoxin mRNA levels, but treatment with inhibitors of p38 MAPK (SB203580) and Jnk (SP600125) did not (Fig 4B). Additionally, use of a broad-spectrum tyro- sine kinase inhibitor, tyrophostin, produced a similar inhibitory effect (data not shown). These results suggest that the early activation of Jak/Stat1, PI3K/Akt and Erk, but not p38 or Jnk, is involved in the IFN- $\gamma$-mediated induction of thioredoxin gene expression. Next, we examined the downstream effectors of these kinases which might act as transcriptional activators for thioredoxin gene expression. In addition to Stat 1 which acts as a key transcription factor during IFN- $\gamma$ signaling, AP-1(c-fos/cjun) and NF- $\mathrm{kB}$ were chosen for analysis because these factors were implicated in the regulation of gene expression involved in redox response. The nuclear translocation profile indicated that there was a strong activation of Stat 1 and c-jun/c-fos within $15 \mathrm{~min}$ and a weak activation of p65/NF- $\mathrm{BB}$ within 30 to $60 \mathrm{~min}$ upon IFN- $\gamma$ treatment (Fig. 4C). The activation of Stat 1 and AP-1 may occur through Jak1- and Erk/Akt-dependent phosphorylation, respectively. Despite a weak activation of p65/NF-kB by IFN- $\gamma$ in these cells, its involvement in thioredoxin gene expression is unlikely, since PDTC (an NF- $\mathrm{KB}$ inhibitor) had no effects on the IFN- $\gamma$-induced thioredoxin mRNA levels. Hence, the data suggest that Stat 1 and AP-1, but not NF- $\kappa$ B may play a role in IFN- $\gamma$ signaling pathways which lead to thioredoxin gene expression.

\section{Role of thioredoxin in the oxidant- or irradiation- induced stress response to regulate immune cell survival from apoptosis mediated byROS}

One of the most recognized functions of thioredoxin is its ability to increase cellular reductive power and reduce proteins that have been damaged by oxidative stress or various ROS-inducing stimuli [36]. Therefore, we first evaluated the effect of ROS-inducing stimuli on thioredoxin gene expression and compared these effects with those of IFN- $\gamma$. As indicated in previous studies [36], hydrogen peroxide or gamma irradiation at sub-lethal doses induced a noticeable up-regulation of thioredoxin gene expression within $24 \mathrm{~h}$ (Fig 5A-a, b). In addition, the magnitude of thioredoxin induction that occurred in response to both IFN- $\gamma$ and irradiation treatment was comparable (2.0 2.5 fold); however, no additive or synergistic effects were observed upon combined treatment. These findings suggest that IFN- $\gamma$ and gamma irradiation induce thioredoxin through a common or converging pathway (Fig 5A-c).

To examine the role that thioredoxin plays in immune cell survival during apoptotic stress, we analyzed the effect of thioredoxin expression on the apoptosis induced by oxidative or radiation stress. We found that monocytic cells generated ROS and showed an apoptotic response upon exposure to 50 Gy of $\gamma$-irradiation, and that transfection of thioredoxin substantially suppressed the ROS levels and partially protected the cells from the irradiation-induced apoptosis (Fig 5B). Similarly, apoptosis induced by 
A

(a)

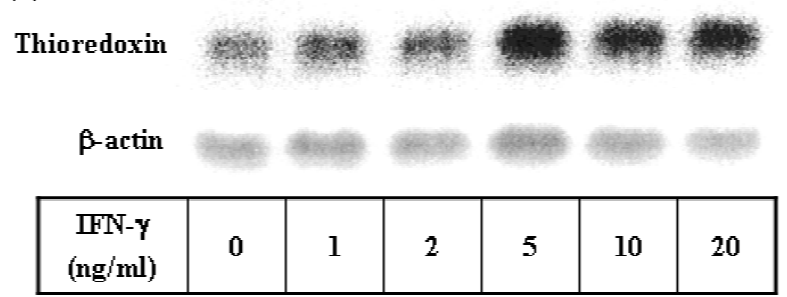

(b)

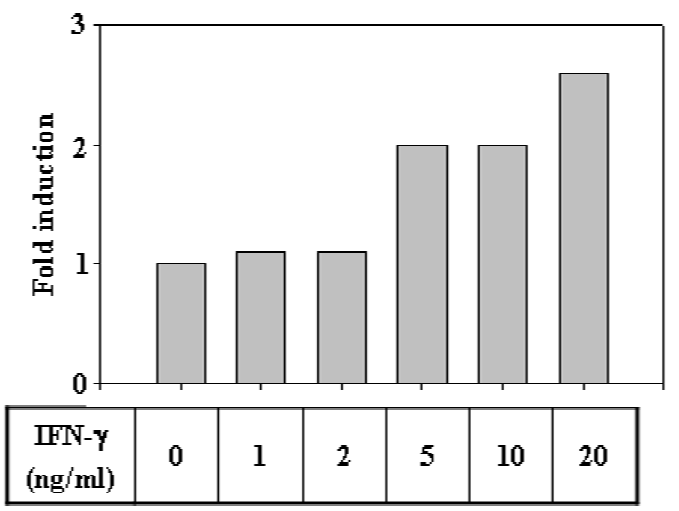

B

(a)

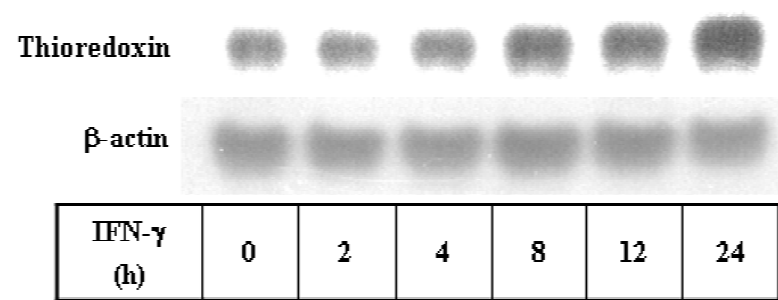

(b)

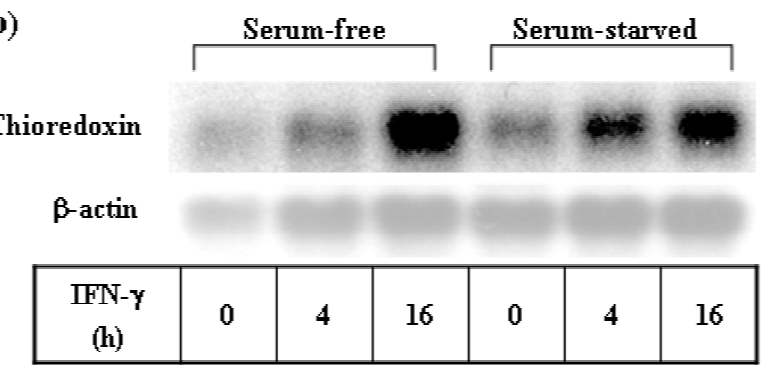

(c)

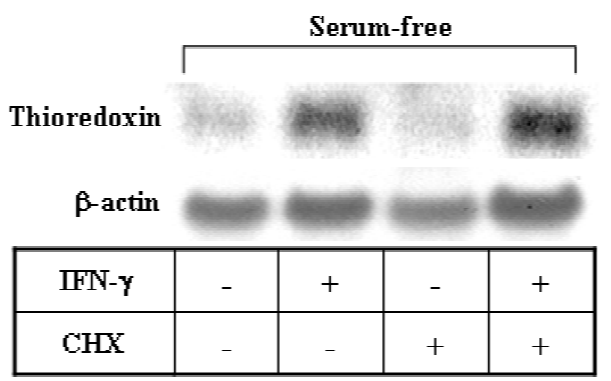

Figure 2

Up-regulation of thioredoxin gene expression by IFN- $\gamma$ in monocytic cells. A. Dose-dependent induction of thioredoxin mRNA by IFN- $\gamma$. THPI monocytic cells $\left(5 \times 10^{6}\right)$ were treated with varying doses of IFN- $\gamma$ in complete media for $24 \mathrm{~h}$, after which the RNA was isolated and the thioredoxin gene expression was analyzed by Northern blot analysis as described in Fig I. Panel a: Northern blot autoradiogram. Panel b: Densitometric analysis of the data in panel a. The values represent the fold induction of thioredoxin mRNA levels, which were calculated after normalization against $\beta$-actin by taking the untreated control value as I. B. Kinetics of thioredoxin gene induction by IFN- $\gamma$ and the effect of cycloheximide. Panel a: THPI cells were treated with IFN- $\gamma(I 0 \mathrm{ng} / \mathrm{ml})$ in complete media for the indicated time periods, after which the RNA was isolated and analyzed for thioredoxin gene expression by Northern blot analysis as described in Fig I. Panel b: THPI cells that had been maintained in complete media were washed thoroughly and then treated with IFN- $\gamma$ (I0 ng/ml) under serum-free conditions ("serum-free") or serum starved conditions for $48 \mathrm{~h}$ prior to IFN- $\gamma$ treatment ("serum-starved"). The cells were then harvested after the indicated time periods, after which their thioredoxin mRNA levels were determined by Northern blot analysis. Panel c: THPI cells were treated with IFN- $\gamma$ under serum-free conditions as described for panel b, with or without pretreatment with cycloheximide $(30 \mu \mathrm{g} / \mathrm{ml})$ for $3 \mathrm{~h}$. The cells were then cultured for an additional $4 \mathrm{~h}$ following IFN- $\gamma$ treatment, after which the thioredoxin mRNA levels were determined by Northern blot.

hydrogen peroxide was substantially suppressed upon forced expression of thioredoxin in target cells (data not shown). The results are in agreement with the study conducted by Ferret et al. [37], which demonstrated that transfected thioredoxin protected THP1 monocytic cells from NO-mediated cellular injury. Together these data indicate that human thioredoxin plays a role in immune cell survival upon exposure of cells to ROS-inducing stimuli, such as hydrogen peroxide or gamma irradiation. 


\section{Regulation of cytokine balance by thioredoxin through the induction of IFN- $\gamma$ during oxidative stress}

To assess the immunological functions of IFN- $\gamma$-induced thioredoxin during oxidative stress, we examined the effect of thioredoxin on $\mathrm{T}$ cell cytokine balance. It has been reported that exogenously added Trx80 stimulates IL-12 production and enhances CD14 expression on monocytes in PBMC cultures [28]. In addition, it has been suggested that the intracellular thiol redox status of macrophages plays a role in the regulation of cytokine balance towards Th1 in thioredoxin-transgenic mice during aging [38]. Conversely, several studies have shown that oxidative stress and ROS signaling tend to increase Th 2 cytokine production and induce a Th2-biased cytokine profile $[39,40]$. Therefore, we evaluated the effect of thioredoxin to determine if it regulates the Th1/Th2 cytokine balance during oxidative stress. It was observed that stimulation with anti-CD3 plus anti-CD28 effectively induced both IL-4 and IFN- $\gamma$ expression in cytokine-producing Jurkat T cells and that hydrogen peroxide treatment selectively suppressed the IFN- $\gamma$ gene expression induced by antiCD3 plus anti-CD28, resulting in the cytokine balance leaning towards Th2 (Fig 6, lane 2 vs. lane 3). Noticeably, in Jurkat T cells that were transfected with thioredoxin, the IFN- $\gamma$ mRNA levels were upregulated, whereas the IL-4 mRNA levels were down-regulated (Fig 6, lane 3 vs. lane $6)$. These results demonstrate that the oxidant-induced Th2-biased cytokine response is counteracted by thioredoxin, which suggests that thioredoxin plays a role in Th1 immunity through the induction of IFN- $\gamma$.

Next, in order to investigate the role of thioredoxin on cytokine production in primary immune cells, we treated human PBMCs with recombinant human thioredoxin (hrTrx) and then analyzed the cytokine-producing cell populations for IFN- $\gamma$ and IL-4 using intracellular cytokine staining (Fig 7A). Upon hrTrx treatment, mitogen-induced IFN- $\gamma$-producing cells were increased (30.8 vs. $38.2 \%)$, while IL-4-producing cells were decreased (16.0 vs. $8.8 \%$ ), which resulted in a clear shift towards Thl. Furthermore, analysis by quantitative RTPCR revealed that, in accordance with the increase in IFN$\gamma$-producing cells, hrTrx treatment significantly up-regulated the mitogen-induced IFN- $\gamma$ mRNA levels by 2-fold (Fig 7B).

\section{Discussion}

As a part of our on-going investigation on the regulation mechanism involved in Th1 and Th2 immune response, we conducted DD-PCR analysis of human PBMCs to screen for novel target genes differentially regulated by Th1 and Th2 cytokines. The results of our screening revealed that human thioredoxin was selectively induced by IFN- $\gamma$, but not by IL-4, in various immune cells. Human thioredoxin was originally identified as a soluble factor produced by HTLV- or EBV-transformed lymphoblastoid cell lines which stimulated the growth of these cell lines [24]. While the constitutive levels of thioredoxin were diverse depending on the cell types [31,33], relatively low thioredoxin mRNA expression levels in immune cells were generally enhanced upon mitogen or oxidant treatment. We have also noted that various mitogens were capable of thioredoxin induction in $\mathrm{T}$ and monocytic cells within $24 \mathrm{~h}$. More importantly, we have demonstrated that thioredoxin is up-regulated up to 3 fold by a prototypic Th1 cytokine IFN- $\gamma$ in various immune cell types including PBMCs and B cells [32] as well as $\mathrm{T}$ and monocytic cells (Fig 1). In monocytic cells, the thioredoxin-inducing effect is specific to IFN- $\gamma$, while other cytokines such as IL-2 and IFN- $\alpha$, had no effect on thioredoxin expression (Fig 1A and $1 \mathrm{~B}$ ). The prior incubation of cells with neutralizing antibodies to human IFN- $\gamma$ suppressed the increase in thioredoxin mRNA levels that was induced by IFN- $\gamma$ and PHA, but not the increase caused by LPS, suggesting that PHA-induced thioredoxin expression is mediated by IFN- $\gamma$ (Fig 1B). The up-regulation of thioredoxin gene expression in monocytic cells was more prominent under serum-free conditions than serum-rich conditions (Fig 2B), which suggests that growth factors contained in the serum may affect the regulation of thioredoxin levels.

To elucidate the regulation mechanism by which the thioredoxin gene is induced by IFN- $\gamma$, we conducted a kinetic analysis and examined the signaling pathways involved in regulation of gene using a monocytic cell line. The increase in mRNA levels induced by IFN- $\gamma$ was kinetically followed by increased production of thioredoxin protein, and the same magnitude of induction was obtained at the mRNA and protein levels. These findings indicate that IFN- $\gamma$-induced thioredoxin gene expression leads to increased protein production. The up-regulation of thioredoxin mRNA by IFN- $\gamma$ was not affected by cycloheximide, a translational inhibitor. This observation suggests that the induction of thioredoxin is a primary response to IFN- $\gamma$, which does not require on-going protein synthesis or other IFN- $\gamma$-induced protein products. Therefore, the early IFN- $\gamma$ signaling pathways would directly influence the activation of transcription factors responsible for the thioredoxin gene expression. The subsequent analysis of the IFN- $\gamma$-activated signaling transduction pathways and the subsequent experiments evaluating the effects of specific signaling inhibitors showed that the IFN- $\gamma$-induced up-regulation of the thioredoxin gene expression involves Jak, PI3k/Akt and Erk-dependent pathways, which lead to the activation of specific transcription factors.

Although several transcription factors have been implicated in the regulation of thioredoxin gene expression in 
A

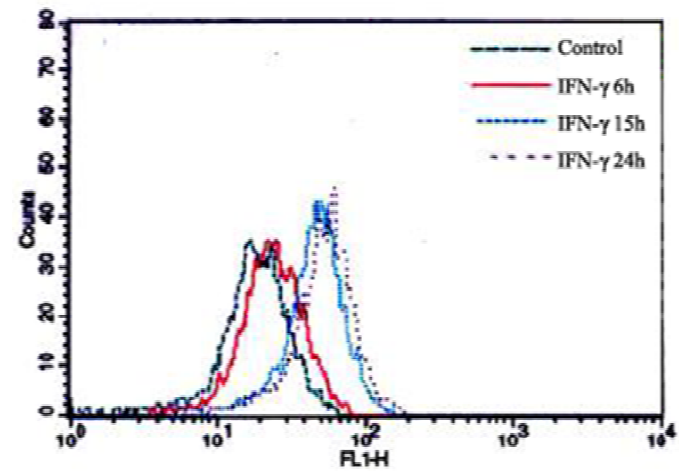

B

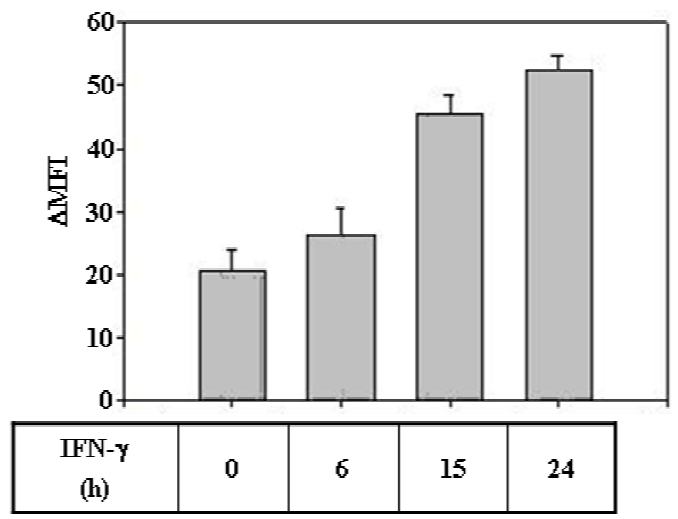

Figure 3

Up-regulation of the thioredoxin protein levels by IFN- $\gamma$. THPI cells $\left(5 \times 10^{5}\right)$ were treated with media alone or with IFN- $\gamma$ under serum-free conditions for the indicated time periods. The cells were then treated with brefeldin $\mathrm{A}$ $(10 \mu \mathrm{g} / \mathrm{ml})$ for $4 \mathrm{~h}$ prior to being harvested, after which they were permeabilized and stained with mouse monoclonal antithioredoxin antibodies and mouse IgG-FITC as described in the text. FACS analysis was performed to determine the intracellular protein levels based on their MFI values. Panel A: A representative FACS histogram. Panel B: $\triangle$ MFI values for thioredoxin levels. Each value shown represents the mean of three independent determinations.

response to oxidative stress, including Ap-1/Ref, NF- $\kappa B$, and ATFII, relatively little is known about the mechanism by which these transcription factors are activated, their binding to responsive elements, or the eventual transcriptional activation of the thioredoxin gene $[41,42]$. However, a close examination of the human thioredoxin gene promoter sequence revealed the presence of putative binding sites for the Stat proteins (GAS). This observation together with the data that early activation of Jak1/Stat 1 during IFN- $\gamma$ signaling and the effect of Jak inhibitors on thioredoxin gene expression, strongly suggest that tyrosine-phophosphorylated Stat 1 plays a direct role in the stimulation of IFN- $\gamma$-induced thioredoxin gene expression (Fig 4-A, B, and 4C). In addition, IFN- $\gamma$ induced early nuclear translocation of c-jun and c-fos, and a weak delayed activation of NF- $\kappa B$ (Fig 4C). The activation of AP-1 and NF-KB by Erk and PI3K/Akt-dependent phosphorylation have been suggested $[43,44]$, which correlates with the result in Fig 4-B. However, the role of these transcription factors in IFN- $\gamma$-activated thioredoxin gene expression needs to be investigated in more detail in future studies.

One of the factors recently found to play a key role in antioxidant response is nuclear factor-erythroid 2-related factor (Nrf). Nrf binds to the antioxidant response element (ARE) present in the promoter of detoxifying or anti-oxidant enzymes such as heme oxygenase-1, glutathione-Stransferase, thioredoxin reductase, and thioredoxin [45]. Because the Nrf binding site located on the thioredoxin promoter overlaps the AP-1 site [46], it is possible that the AP-1 activating signal of IFN- $\gamma$ replaces the transcriptional activation of the thioredoxin gene via the Nrf/ARE element. However, few studies evaluating the regulation mechanism of thioredoxin gene expression by cytokines or growth factors have been conducted to date. Therefore, detailed studies evaluating the IFN- $\gamma$ signaling pathways that lead to transcriptional activation of the thioredoxin gene should be performed to provide information regarding the mechanism by which transcriptional regulation of thioredoxin expression occurs.

The induction of thioredoxin expression by IFN- $\gamma$ noted in various immune cells in our study may have an important functional implication. We found that sub-lethal doses of hydrogen peroxide or gamma irradiation induced thioredoxin, but that this induction was delayed (Fig 5). This finding is in agreement with the well-recognized roles that thioredoxin plays in defense against oxidants and radiation stress generating ROS. However, the administration of lethally high doses of these agents often leads to the early suppression of thioredoxin levels and subsequent cell death (data not shown). In our study, IFN- $\gamma$-induced thioredoxin gene expression occurred earlier (4 h; Fig 2) than oxidative- or radiation stress-mediated induction of thioredoxin (16-24 h), and co-treatment with IFN- $\gamma$ and irradiation stress did not exert a synergistic effect on the induction of thioredoxin (Fig 5A). Taken together, these observations suggest that gamma irradiation and IFN- $\gamma$ induce thioredoxin expression through a common pathway, and that IFN- $\gamma$ acts as a mediator of irradiationinduced thioredoxin up-regulation.

Thioredoxin has long been recognized for its ability to protect cells from apoptotic stress. For example, in a murine lymphoid cell line WEHI7.2, the transfection and over-expression of human thioredoxin was found to sup- 
A

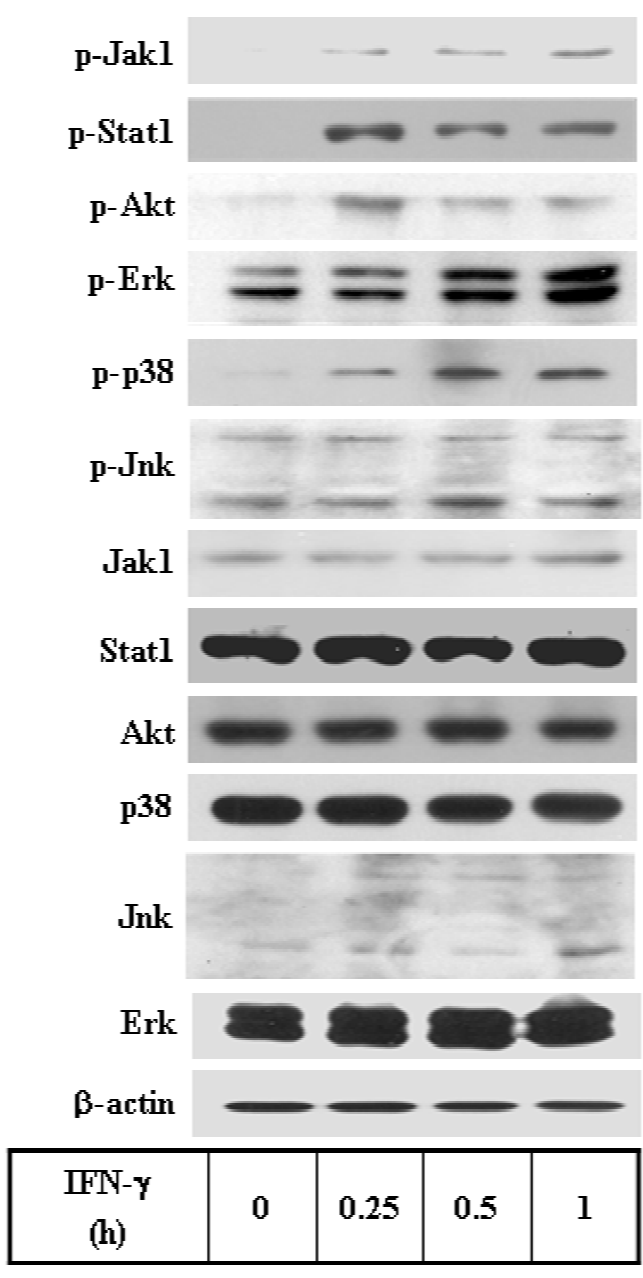

B

\begin{tabular}{|c|c|c|c|c|c|c|c|c|}
\hline Thioredoxin & cis. & 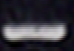 & $=1$ & $\Rightarrow$ & 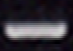 & 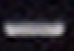 & sing & 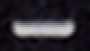 \\
\hline$\beta$ - actin & cants & 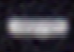 & sest & 5 & 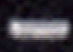 & 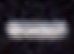 & 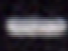 & 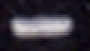 \\
\hline IFN-y & - & + & + & + & + & + & + & + \\
\hline Inhibitor & - & - & $\mathbf{A G}$ & PD & SB & $\mathbf{S P}$ & $\mathbf{L Y}$ & PDTC \\
\hline
\end{tabular}

C

\begin{tabular}{|l|c|c|c|c|c|c|c|c|}
\hline & \multicolumn{4}{|c|}{ cytosol } & \multicolumn{5}{c|}{ nuclear } \\
\hline IFN-y (h) & 0 & 0.25 & 0.5 & 1 & 0 & 0.25 & 0.5 & 1 \\
\hline
\end{tabular}

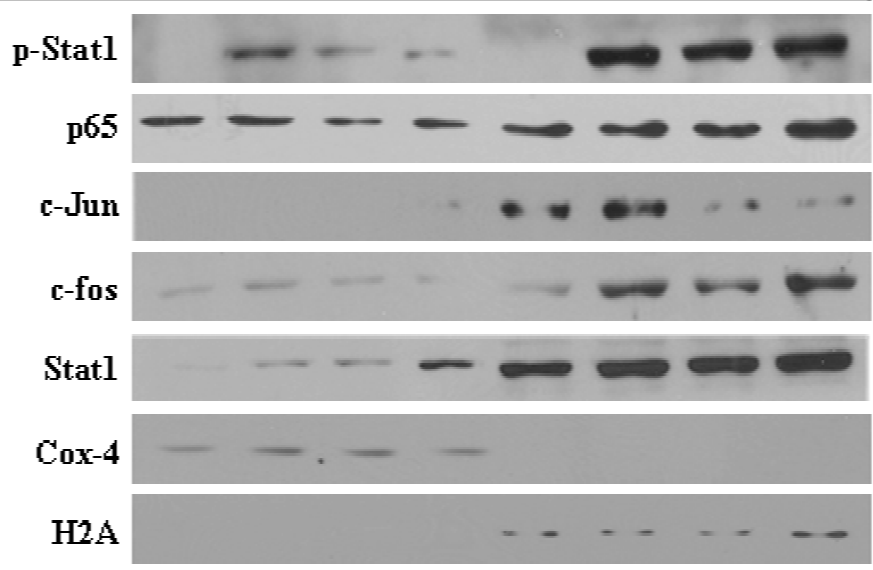

\section{Figure 4}

Analysis of signaling pathways activated by IFN- $\gamma$ and the effects of signaling inhibitors on thioredoxin gene expression. A. Analysis of Jak, Akt, and MAPK pathways during IFN- $\gamma$ signal transduction in THPI cells. THPI cells $\left(I \times 10^{6}\right)$ were treated with media alone or IFN- $\gamma$ under serum-free conditions for the indicated times. The total cell lysates were then prepared and analyzed by Western blot to determine the activation status of Jak I/Stat I, Akt, and MAPKs as described in the text. B. Effects of signaling inhibitors on IFN- $\gamma$-induced thioredoxin gene expression. THPI cells (I

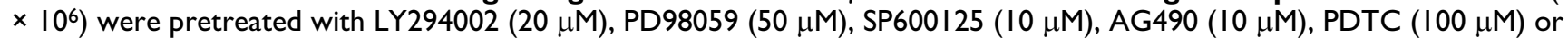
SB203580 $(20 \mu \mathrm{M})$ for I $\mathrm{h}$ and then cultured for an additional $24 \mathrm{~h}$ in the presence or absence of IFN- $\gamma$ under serum-free conditions. The total RNA was isolated and the thioredoxin mRNA levels were then analyzed by RT-PCR. C. Analysis of activation and nuclear translocation of Stat I, NF- $\kappa$ B, and AP-I induced by IFN- $\gamma$ in THPI cells. Cells $\left(5 \times 10^{6}\right)$ were treated with media alone or IFN- $\gamma(10 \mathrm{ng} / \mathrm{ml})$ under serum-free conditions for the indicated times. The cells were then harvested and used to prepare cytoplasmic or nuclear extracts. The extracts were then subjected to Western blot to determine the activation status of Stat I, c-Jun, c-fos or NF- $\mathrm{B}$, using antibodies to anti-phosphotyrosine Stat I, anti-Stat I, c-Jun, c-fos and NF- $\kappa B$ (p65). As internal controls, Cox-4 and H2A were used for cytosolic and nuclear marker proteins, respectively.

press the apoptosis induced by glucocorticoid, etoposide, and peroxide, in a manner similar to $\mathrm{Bcl} 2$ over-expression [47]. However, the mechanism by which thioredoxin exerts its anti-apoptotic effect against different stress responses is not clearly known, while it appears to vary depending on the nature of the stimuli and the types of 
cells involved $[48,49]$. However, results of our study indicates that thioredoxin over-expression suppresses the irradiation- or oxidant-induced apoptosis in immune cell lines, and that such anti-apoptotic function of thioredoxin is associated with the ROS-scavenging effect observed in thioredoxin-transfected cells.

The redox-regulation of mononuclear phagocytes plays an important physiological role in the defense against microbial infection and inflammation, as well as in the proper cellular response to a wide variety of stress conditions evoked by hypoxia/oxidants, nutrient starvation, DNA damaging agents, and ionizing radiation [50]. It is now apparent that thioredoxin is a key defense molecule involved in the regulation of homeostasis in cells subjected to diverse stresses $[19,50]$. On the other hand, the functions of IFN- $\gamma$ as an immuno-regulatory cytokine include macrophage activation for effective antigen processing and presentation upon pathogen uptake via up-regulation of MHC molecules [51], activation of lysosomal enzymes [52], and regulation of ROS-generating enzymes such as NADPH oxidases [53,54], myeloperoxidases [55] and superoxide dismutases [56]. Recently, an IFN- $\gamma$-inducible thiol-containing lysosomal enzyme, GILT, which plays a role in the control of oxido-reduction reactions in the lysosome during antigen processing, was identified $[57,58]$. These findings indicate that there is a casual mechanistic link between redox regulation of the thioredoxin system and IFN- $\gamma$-mediated macrophage activation, which functions as an important defense mechanism that maintains immune homeostasis upon infection and inflammation.

It has been reported that mammalian thioredoxins are produced in several forms different in size and structure. In addition to the classical cytosolic Trx-1 [31] and mitochondrial Trx-2 [59], a minor cytosolic TRP14 [60] and Trx80 [61] have been identified. The 12 kD Trx-1 and Cterminal truncated $10 \mathrm{kD}$ Trx 80 are known to be secreted from the cell and believed to act as a co-cytokine to regulate immune cell functions $[61,62]$. Denaturing SDSPAGE analysis of IFN- $\gamma$-treated THP-1 cells revealed that the IFN- $\gamma$-induced thioredoxin identified in the present study has a deduced molecular weight of $12 \mathrm{kD}$ (Fig S1) and an apparent molecular weight of $14 \mathrm{kD}$ (data not shown), which indicate that it is the cytosolic full-length Trx-1 [31]. The reported cytokine-like activities of both full-length and truncated thioredoxin include stimulation of immune cell proliferation, macrophage differentiation and chemotaxis, and production of inflammatory cytokines such as IL-I, IL-6, IL-8, and TNF [63-65].

Of particular interest is the finding that Trx80, when cotreated with IL-2, promoted the production of IL-12 and IFN- $\gamma$ by human PBMCs [28], which suggests that thiore- doxin can act as a potential inducer of Th1 immunity and that there is a functional link between thioredoxin and IFN- $\gamma$. In line with this, our data demonstrate that thioredoxin over-expression induces $\mathrm{T}$ cells to counteract the oxidant-induced Th2 bias and reverse cytokine balance by up-regulating IFN- $\gamma$ gene expression (Fig 6). Furthermore, a Th1-inducing effect of thioredoxin was observed in human primary $\mathrm{CD} 4+\mathrm{T}$ cells, as shown by changes between the IL-4 and IFN- $\gamma$-producing populations in response to treatment with hrTrx (Fig 7A). Specific induction of IFN- $\gamma$ mRNA in PBMCs treated with hrTrx further supported the up-regulation of Th1 response by thioredoxin (Fig 7B). The induction of thioredoxin by IFN- $\gamma$ and the restoration of IFN- $\gamma$ levels by thioredoxin during oxidative stress in immune cells found in this study, suggest that thioredoxin and IFN- $\gamma$ may have evolved to serve complementary functions through positive feedback mechanisms during immune inflammatory conditions.

\section{Conclusion}

We have demonstrated that human thioredoxin is a novel target gene induced by IFN- $\gamma$. In addition, we showed that thioredoxin may play a role in the protection of immune cells from apoptosis and in the counter-regulation of cytokine production evoked by ROS-generating stimuli. Therefore, thioredoxin induced by IFN- $\gamma$ upon infection, stress, or immune triggers for Th1 immune response appears to act as a protective factor that maintains immune cell homeostasis through mechanisms involving ROS-scavenging, anti-apoptotic and cytokine-regulating functions.

\section{Methods \\ Cells and cell culture}

PBMCs were isolated from the freshly-drawn blood of healthy donors using Ficoll-Hypaque density gradient centrifugation. Flow cytometry revealed that the mononuclear cell preparation typically contained approximately $70 \%$ T cells, 15 20\% B cells, and 10 15\% monocytes. The human monocytic cell lines, THP1 and U937, and the T lymphocytic leukemic cell line, Jurkat, were obtained from ATCC and maintained in complete RPMI media containing $10 \mathrm{mM}$ Hepes (pH 7.5), $50 \mu \mathrm{M} \beta$-mercaptoethanol, and 10\% FBS (Life Technologies Inc., Grand Island, NY USA). The cells were then treated with recombinant human IFN- $\gamma$, IL-4, IL-2 (R \& D systems, Minneapolis, MN, USA) or IFN- $\alpha$ (Roche, Nutley, NJ USA) in the presence or absence of serum, after which the cells were cultured for various lengths of time at $37^{\circ} \mathrm{C}$ under $5 \%$ $\mathrm{CO}_{2}$.

\section{$D D-P C R$ screening and cloning}

PBMCs were cultured in the presence of $10 \mathrm{ng} / \mathrm{ml}$ of IFN$\gamma$ and/or IL-4, after which the total RNA was isolated using $4 \mathrm{M}$ GITC and $5 \mathrm{M} \mathrm{CsCl}$ and ultracentrifugation. DD-PCR 
(a)

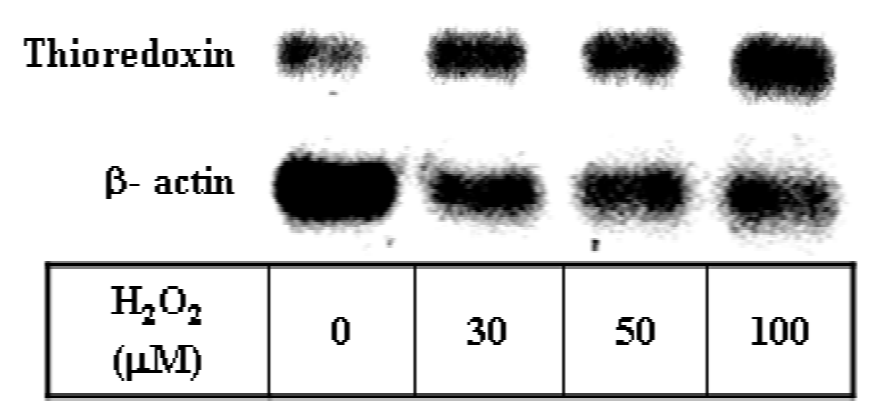

(b)

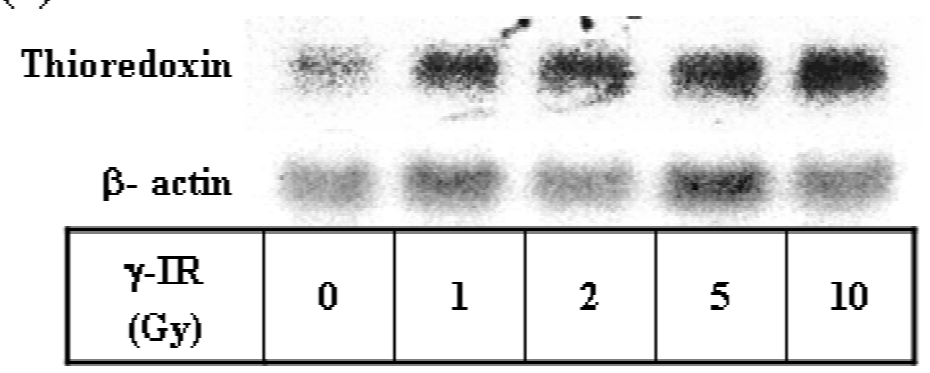

(c)

Thioredoxin tol
B- actin
\begin{tabular}{|c|c|c|c|c|}
\hline IFN-Y & - & + & - & + \\
\hline Y-IR & - & - & + & + \\
\hline
\end{tabular}
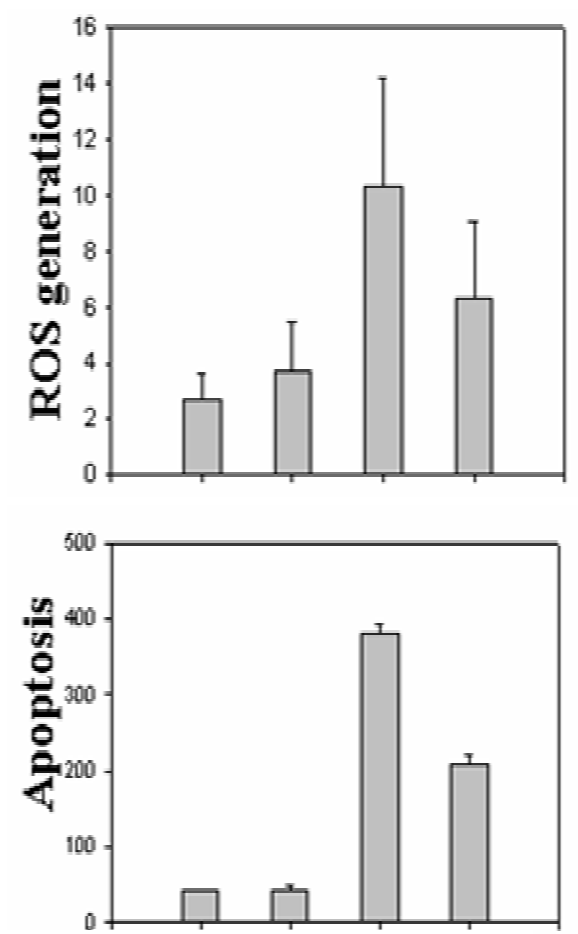

\begin{tabular}{|c|c|c|c|c|}
\hline $\operatorname{Trx}$ & - & + & - & + \\
\hline $\mathrm{Y}-\mathrm{IR}$ & - & - & + & + \\
\hline
\end{tabular}

\section{Figure 5}

Role of thioredoxin in the oxidant- or gamma irradiation-induced stress response and apoptosis. A. Induction of thioredoxin gene expression by oxidants and gamma irradiation. THPI monocytic cells were treated with media alone or with varying doses of hydrogen peroxide for $24 \mathrm{~h}$ (Panel a). Cells were exposed to varying doses of gamma irradiation $(\gamma-\mathrm{IR})$ and further cultured for $16 \mathrm{~h}$ (Panel b). Cells were treated with media alone, IFN- $\gamma(10 \mathrm{ng} / \mathrm{ml}), \gamma-\mathrm{IR}$ (5 Gy), and IFN- $\gamma$ plus $\gamma$-IR for $16 \mathrm{~h}$ (Panel c). Total RNA was prepared and analyzed by Northern blot to determine the thioredoxin mRNA levels. B. Protective function of thioredoxin against gamma irradiation-induced apoptosis. U937 monocytic cells were either mock-transfected with empty vector $(-)$ or transfected with thioredoxin expression construct $(+)$ and then cultured for $40 \mathrm{~h}$. The cells were then exposed to $50 \mathrm{~Gy}$ of $\gamma$-IR, after which they were analyzed for ROS generation at $30 \mathrm{~min}$ (upper box) and apoptosis at $16 \mathrm{~h}$ (lower box) as described in the text.

assays were performed using a DD-PCR kit (RNAimage, GenHunter, Nashville, USA) according to the manufacturer's instructions, and the amplified products were displayed on a $6 \%$ polyacrylamide gel. Next, PCR product bands that were selected based on their differential expression were purified from the gel, reamplified, and ligated into a pUC $18 / S m a I$ vector at $16^{\circ} \mathrm{C}$ for $48 \mathrm{~h}$. E. Coli was then transformed with the ligated vectors, after which 
Jurkat T cells

\begin{tabular}{|c|c|c|c|c|c|c|}
\hline & \multicolumn{3}{|c|}{ Mock } & \multicolumn{3}{c|}{ Trx } \\
\hline $\mathrm{H}_{2} \mathrm{O}_{2}$ & - & - & + & - & - & + \\
\hline CD3/CD28 & - & + & + & - & + & + \\
\hline IFN-y & & & & \\
IL-4 & & \\
Thioredoxin & \\
B-actin & \\
\hline
\end{tabular}

\section{Figure 6}

The effects of oxidants and thioredoxin on cytokine production in Jurkat $\mathbf{T}$ cells: Thioredoxin up-regulates IFN- $\gamma$ production and counteracts Th2 cytokine bias caused by oxidants. Jurkat $T$ cells were either mocktransfected with empty vector (Mock) or transfected with thioredoxin expression construct (Trx) and then incubated for $24 \mathrm{~h}$. The cells were then pretreated with hydrogen peroxide $(400 \mu \mathrm{M})$ for I $\mathrm{h}$, after which they were incubated with media alone or with human anti-CD3 $(\mathrm{I} \mu \mathrm{g} / \mathrm{ml})$ plus antiCD28 $(\mathrm{l} \mu \mathrm{g} / \mathrm{ml})$ to stimulate cytokine production for $4 \mathrm{~h}$. RT-PCR was then performed to determine the mRNA levels of IL-4, IFN- $\gamma$, and thioredoxin.

clones that contained the insert were selected. The plasmids were then purified and sequenced using a previously described method [29].

\section{Northern blot and RT-PCR analysis of thioredoxin}

Cells were treated with various cytokines for the indicated times, after which the total RNA was isolated. Next, the RNA was separated on a $1 \%$ agarose gel, transferred to nylon membranes, and then hybridized with a radiolabeled probe of a full-length human thioredoxin cDNA. Densitometric analysis of the blots was then performed using ImageQuant (Molecular Dynamics, Sunnyvale, CA, USA). RT-PCR analysis of thioredoxin was performed using standard protocols. Briefly, RNAs $(1 \sim 2 \mu \mathrm{g})$ were reverse-transcribed and then subjected to 30 cycles of PCR amplification using a thermal cycler (GeneAmp PCR System 2400, Applied Biosystems, USA) and the following thioredoxin specific primers: 5' primer, CTTTGGATCCATTTCCATC; 3' primer, GCATTAATGTTTTATTGTCACG., as described [32].

\section{Intracellular staining of thioredoxin}

Cells were cultured in serum-free medium and then treated with IFN- $\gamma$ for various time periods. To measure the intracellular levels of thioredoxin, brefeldin A (Sigma,
St. Louis, MO, USA) was added to the cells 4 to $6 \mathrm{~h}$ prior to harvest. Cells were then permeabilized in PBS buffer containing $0.5 \%$ saponin and $1 \%$ BSA, after which they were stained with mouse monoclonal anti-human thioredoxin antibodies (American Diagnostics Inc., Stamford, Connecticut, USA) and anti mouse IgG-FITC. Flow cytometric analysis using a FACS Calibur (BD Bioscience, Mountain View, CA, USA) was then conducted to determine the mean fluorescence intensity (MFI) values. The $\Delta$ MFI for each sample was then calculated by subtracting the MFI of cells that were stained with anti-thioredoxin antibodies and anti-mouse IgG-FITC from the MFI of cells that were stained with anti-mouse IgG-FITC only. All values represent a mean of three independent determinations.

\section{Thioredoxin transfection}

Cells were plated at a density of $5 \times 10^{6} /$ well in 6 -well plates. cDNA expression constructs for human thioredoxin, hTRX-WT (kindly provided by Dr. J. Yodoi, Kyoto Univ.) cloned into pcDNA Xpress vector or empty vectors were then introduced into the cells using Superfect reagent (Qiagen, Valencia, USA) according to the manufacturer's instructions. At two days (40 to $48 \mathrm{~h}$ ) after transfection, the cells were harvested and the thioredoxin expression levels were determined by immunoblotting using monoclonal anti-human thioredoxin antibodies.

\section{Immunoblotting}

Cells were harvested and the total, cytosolic, or nuclear extracts were then prepared. Next, the proteins were fractionated by SDS-PAGE, transferred to PVDF membranes, and then subjected to immunoblot analysis using antibodies to thioredoxin (American Diagnostica Inc.), p65 NF-kB (Upstate Biotechnology, Lake Placid, NY, USA), H2A, Akt, p-Akt, Erk, p-Erk, Jnk, p-Jnk, p38 and p-p38 (Cell Signaling Technologies, Beverly, MA, USA), Jak1, pJak1, Stat1, p-Stat1, c-fos and c-jun (Santa Cruz Biotechnology, Santa Cruz, CA, USA), Cox-4 (Invitrogen, Carlsbad, USA) or $\beta$-actin using an ECL detection kit (Amersham, Uppsala, Sweden).

\section{Apoptosis assays}

Cells were treated with 10 to $500 \mu \mathrm{M}$ hydrogen peroxide or irradiated at room temperature with a ${ }^{137} \mathrm{Cs} \gamma$-source irradiator at a dose rate of $5.66 \mathrm{~Gy} / \mathrm{min}$ using an IBL 437 type $\mathrm{H}$ irradiator (CIS Biointernational, Nice, France) at 5 to 50 Gys as described previously [66]. The cells were then incubated at $37^{\circ} \mathrm{C}$, after which apoptosis was determined by cytochrome $\mathrm{C}$ release analysis and Annexin $\mathrm{V}$ staining as described $[32,67]$.

\section{ROS measurement}

After exposure of the cells to hydrogen peroxide or gamma irradiation for the indicated time periods, cells were collected and stained with $5 \mu \mathrm{M}$ each of DHE (Calbiochem, 
A

Human peripheral CD4+ $T$ cells

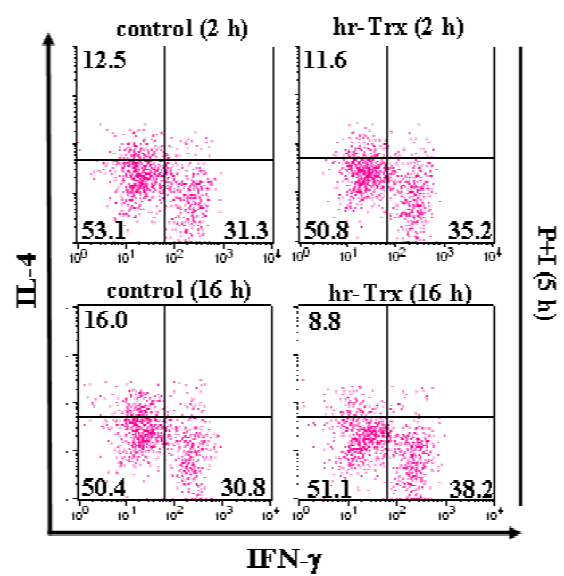

Human PBMCs

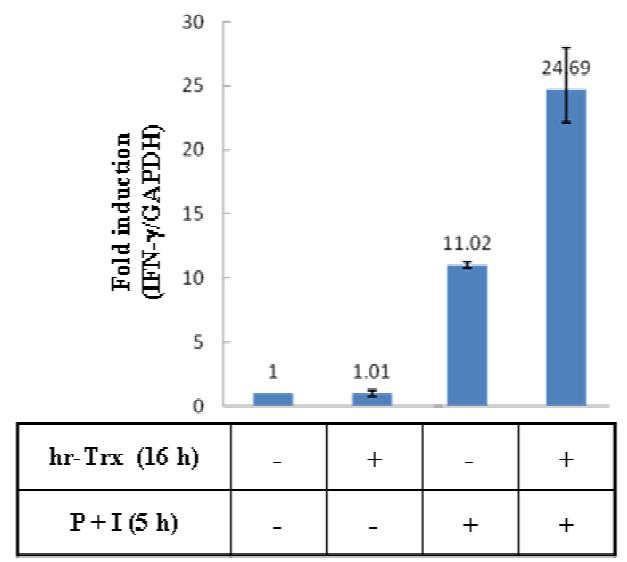

Figure 7

Effects of recombinant thioredoxin (hr-Trx) on cytokine production in primary immune cells. $A$. Thioredoxin modulates IFN- $\gamma$ - vs. IL-4-producing CD4+ $\mathrm{T}$ cell populations. Human peripheral lymphocytes $\left(I \times 10^{6}\right)$ were treated with media alone or with human recombinant thioredoxin ( $\mathrm{hr}-\mathrm{Trx}$ ) for 2 or $16 \mathrm{~h}$. The cells were then stimulated with PMA $(30 \mathrm{ng} / \mathrm{ml})+$ ionomycin (I $\mu \mathrm{g} / \mathrm{ml})$ in the presence of brefeldin A $(10 \mu \mathrm{g} / \mathrm{ml})$ for $5 \mathrm{~h}$, after which they were permeabilized and stained with FITC-conjugated anti-human IFN- $\gamma$ antibodies and PE-conjugated antihuman IL-4 antibodies. These cells were then restained with PerCP-conjugated anti-human CD4 antibodies to enable separation of the Th cells. FACS analysis was performed to determine the intracellular cytokine levels. B. Thioredoxin increases the IFN- $\gamma$ mRNA levels in human PBMCs. Human PBMCs $\left(I \times 1^{6}\right)$ were treated with media alone or with $\mathrm{hr}$-Trx for $16 \mathrm{~h}$. The cells were then stimulated with PMA $(20 \mathrm{ng} / \mathrm{ml})+$ ionomycin $(0.5 \mu \mathrm{g} / \mathrm{ml})$ for $5 \mathrm{~h}$. The total RNA was then isolated and analyzed by real time RT-PCR using primers specific for IFN- $\gamma$. IFN- $\gamma$ mRNA expression levels were normalized with the internal control, GAPDH.
San Diego, CA, USA) and $\mathrm{H}_{2}$ DCF-DA (Sigma) to enable the detection of superoxide anion and hydrogen peroxide, respectively. The fluorescence was then measured by FACSCalibur analysis. The ROS levels are shown as fluorescence intensity, and all values shown represent the mean of three independent determinations.

\section{Cytokine gene expression analysis}

Jurkat $\mathrm{T}$ cells were stimulated with anti-CD3 plus antiCD28 with or without pretreatment with hydrogen peroxide. Following incubation for $4 \mathrm{~h}$, the total RNA was isolated and used for RT-PCR analysis of the cytokine transcripts using primers specific for human IL-4, IFN- $\gamma$, and $\beta$-actin as described previously [68].

\section{Intracellular cytokine staining}

Human PBMCs were treated with human recombinant thioredoxin (hr-Trx, BD Biosciences) for 2 or $16 \mathrm{~h}$. For intracellular cytokine staining, the cells were stimulated with $30 \mathrm{ng} / \mathrm{ml} \mathrm{PMA}$ and $1 \mu \mathrm{g} / \mathrm{ml}$ ionomycin for $5 \mathrm{~h}$ in the presence of brefeldin A at $37^{\circ} \mathrm{C}$. Next, the cells were fixed and permeabilized in Cytofix/Cytoperm buffer, after which they were stained with FITC-conjugated anti-IFN- $\gamma$ and PE-conjugated anti-IL-4 (BD Biosciences). To separate the CD4+ T cells, these cells were stained with PerCP-conjugated anti-CD4 (BD Biosciences). Flow cytometric analysis was then performed using FACSCalibur to determine the ratio (\%) of cytokine-producing cells.

\section{Real-time RT-PCR}

Human PBMCs were treated with hr-Trx for $16 \mathrm{~h}$ and then further cultured with $20 \mathrm{ng} / \mathrm{ml}$ PMA and $0.5 \mu \mathrm{g} / \mathrm{ml}$ ionomycin for $5 \mathrm{~h}$. Total RNA $(1 \mu \mathrm{g})$ was then reverse-transcribed, after which real-time PCR amplification with iQ SYBR Green (Bio-Rad) was performed using a Mastercycler realplex thermalcylcer (Eppendorf AG, Hamburg, Germany). The results were normalized against GAPDH by comparing the fold change in the expression of IFN- $\gamma$ mRNA to the expression of GAPDH using the $2^{\Delta \Delta \mathrm{ct}} \mathrm{com}$ parative expression method. The following primers were used: for IFN- $\gamma$ ( 198 bases), 5'primer, TCCCATGGGTTGTGTGTTTA; 3' primer, AAGCACCAGGCATGAAATCT; for GAPDH (178 bases): 5' primer, GACATCAAGAAGGTG GTGAA; 3' primer, TGTCATACCAGGAAATGAGC.

\section{Abbreviations}

DD-PCR: differential display-polymerase chain reaction; $\gamma$-IR: gamma irradiation; Jak: Janus tyrosine kinase; PBMCs: peripheral blood mononuclear cells; ROS: reactive oxygen species; RT-PCR: reverse transcription based polymerase chain reaction; Stats: signal transducers and activators of transcription; UTR: untranslated region.

\section{Authors' contributions}

The authors' contributions to the present study were as follows: S-HK performed the thioredoxin expression anal- 
ysis, ICC, and RT-PCR to evaluate the cytokine expression. JO analyzed the IFN- $\gamma$ signaling pathways and transcription factor activation, and conducted the thioredoxin over-expression experiments. J-YC and J-YJ performed experiments in the initial stage of this work, including DD-PCR, cloning and Northern blot analysis of thioredoxin. M-WK conducted the ROS and apoptosis-related work. C-EL designed the research, analyzed the data, and wrote the manuscript.

\section{Additional material}

\section{Additional file 1 \\ Identification of human thioredoxin as an IFN- $\gamma$-induced target gene.Identification of thioredoxin as an IFN- $\gamma$-induced target gene. Panel a: After isolation, PBMCs $\left(1 \times 10^{7} /\right.$ sample $)$ were treated with media alone or with $10 \mathrm{ng} / \mathrm{ml}$ of IFN- $\gamma$ and/or IL-4 for $24 \mathrm{~h}$. The total RNA was then isolated and processed for DD-PCR analysis with oligo-dT $\left(H-T_{11} A\right)$ and arbitrary H-APG $(A)$ primers using a DD-PCR kit as described in the text [29], after which the products were displayed on $6 \%$ polyacrylamide gels. Clone A1 was detected as a specific product induced by IFN- $\gamma$ treatment. Panel $b$ : PBMCs $\left(1 \times 10^{7} /\right.$ sample $)$ were treated with media alone, IFN- $\gamma$, or IL-4 (10 ng/ml each) as indicated. The total RNA was then isolated and analyzed for MRNA that had hybridized with the labeled Clone A1 probe. A single RNA species that was 550 bases in size was detected. Panel $c$ : The nucleotide sequence of Clone A1 corresponds to the 3' portion of human thioredoxin cDNA. Upper panel: Complete nucleotide sequence of human thioredoxin. The Clone A1 sequence is indicated by bold characters. The initiation (ATG) and the termination (TAA) codons are underlined. Lower panel: Amino acid sequence of human thioredoxin showing catalytic redox-sensing CGPC residues. Click here for file \\ [http://www.biomedcentral.com/content/supplementary/1471- 2172-9-64-S1.doc] \\ Additional file 2 \\ RT-PCR analysis of thioredoxin gene expression induced by IFN- $\gamma$ or IL-4 in immune cell lines. Jurkat T cells $\left(2 \times 10^{6}\right)$ (Panel a) or THP1 monocytic cells $\left(5 \times 10^{6}\right)$ (Panel $\left.b\right)$ were treated with media alone, IL-4, or IFN- $\gamma$ as in Fig 1-A. The total RNA was then isolated and RT-PCR was performed using primers specific for the full-length thioredoxin cDNA. $\beta$ - actin was used as an internal control. \\ Click here for file \\ [http://www.biomedcentral.com/content/supplementary/1471- 2172-9-64-S2.doc]}

\section{Acknowledgements}

This study was supported by the Samsung Research Fund from Sungkyunkwan University and Research Grants from KOSEF (2007-00979) and KRF (E-00190).

\section{References}

I. Boehm U, Klamp T, Groot M, Howard JC: Cellular responses to interferon-gamma. Annu Rev Immunol 1997, I 5:749-795.

2. Schroder K, Hertzog PJ, Ravasi T, Hume DA: Interferon-gamma: an overview of signals, mechanisms and functions. J Leukoc Biol 2004, 75:163-189.

3. Shtrichman R, Samuel CE: The role of gamma interferon in antimicrobial immunity. Curr Opin Microbiol 200 I, 4:25I-259.
4. Young HA, Hardy KJ: Role of interferon-gamma in immune cell regulation. J Leukoc Biol 1995, 58:373-38I.

5. Driggers PH, Ennist DL, Gleason SL, Mak WH, Marks MS, Levi BZ, Flanagan JR, Appella E, Ozato K: An interferon gamma regulated protein that binds the interferon-inducible enhancer element of MHC I gene. Proc Natl Acad Sci USA 1990, 87:3743-3747.

6. Liu J, Guan X, Ma X: Interferon regulatory factor I is an essential and direct transcriptional activator for interferon gamma-induced RANTES/CCL5 expression in macrophages. J Biol Chem 2005, 280:24347-24355.

7. Hovanessian AG: Interferon-induced and double-stranded RNA-activated enzymes: a specific protein kinase and 2',5'oligoadenylate synthetases. J Interferon Res 1991, I I: 199-205.

8. Takizawa T, Ohashi K, Nakanishi Y: Possible involvement of double-stranded RNA-activated protein kinase in cell death by influenza virus infection. J Virol 1996, 70:8|28-8I32.

9. Williams BRG, Kerr IM: Inhibition of protein synthesis by 2', 5'linked adenine oligonucleotides in intact cells. Nature 1978 276:88-90.

10. Mohan K, Ding Z, Hanly Z, Issekutze TB: IFN-gamma-inducible T cell alpha chemoattractant is a potent stimulator of normal human blood $T$ lymphocyte transendothelial migration: differential regulation by IFN-gamma and TNF-alpha. J Immunol 2002, 168:6420-6428.

II. Rollins BJ, Yoshimura T, Leonard EJ, Pober JS: Cytokine-activated human endothelial cells synthesize and secrete a monocyte chemoattractant, MCP-I/JE. Am J Pathol 1990, 136: I229-1233.

12. Tsujimoto M, Yip YK, Vilcek J: Interferon-gamma enhances expression of cellular receptors for tumor necrosis factor. J Immunol 1986, I36:244I-2444.

13. Decker T, Lew DJ, Mirkovitch J, Darnell JE Jr: Cytoplasmic activation of GAF, an IFN-gamma-regulated DNA-binding factor. EMBO J I991, 10:927-932.

14. Shikata A, Sugimoto T, Hosoi H, Sotozono Y, Shikata T, Sawada T, Parada LF: Increased expression of trk proto-oncogene by gamma-interferon in human neuroblastoma cell lines. Jpn J Cancer Res 1994, 85: 122-126.

15. Deiss LP, Feinstein E, Berissi H, Cohen O, Kimchi A: Identification of a novel serine/threonine kinase and a novel I $5 \mathrm{kD}$ protein as a potential mediator of gamma interferon-induced cell death. Genes Dev 1995, 9:15-30.

16. $\mathrm{Xu} X, \mathrm{Fu} X Y$, Plate J, Chong AS: IFN-gamma induces cell growth inhibition by Fas-mediated apoptosis: requirement of STATI protein for up-regulation of Fas and FasL expression. Cancer Res 1998, 58:2832-2837.

17. Casagrande S, Bonetto V, Fratelli M, Gianazza E, Eberini I, Massignan T, Salmona M, Chang G, Holmgren A, Ghezzi P: Glutathionylation of human thioredoxin: a possible crosstalk between the glutathione and thioredoxin systems. Proc Natl Acad Sci USA 2002, 99:9745-9749.

18. Hirota $\mathrm{K}$, Nakamura $\mathrm{H}$, Masutani $\mathrm{H}$, Yodoi J: Thioredoxin superfamily and thioredoxin-inducing agents. Ann N Y Acad Sci 2002, 957:189-199.

19. Nordberg J, Arner ES: Reactive oxygen species, antioxidants, and the mammalian thioredoxin system. Free Radic Biol Med 200I, 31:1287-I3|2

20. Soderberg A, Sahaf B, Rosen A: Thioredoxin reductase, a redoxactive selenoprotein, is secreted by normal and neoplastic cells: presence in human plasma. Cancer Res 2000, 60:228I-2289.

21. Kondo N, Ishii Y, Kwon YW, Tanito M, Horita H, Nishinaka Y, Nakamura $\mathrm{H}$, Yodoi J: Redox-sensing release of human thioredoxin from $T$ lymphocytes with negative feedback loops. J Immunol 2004, I 72:442-448.

22. Sumida $Y$, Nakashima $T$, Yoh $T$, Nakashima $Y$, Ishikawa $H$, Mitsuyoshi H, Sakamoto Y, Kashima K, Nakamura H, Yodoi J: Serum thioredoxin levels as an indicator of oxidative stress in patients with hepatitis C virus infection. J Hepatol 2000, 33:616-622.

23. Nilsson J, Söderberg O, Nilsson K, Rosén A: Thioredoxin prolongs survival of B-type chronic lymphocytic leukemia cells. Blood 2000, 95: I 1420-I426.

24. Yodoi J, Tursz T: ADF, a growth-promoting factor derived from adult $T$ cell leukemia and homologous to thioredoxin: involvement in lymphocyte immortalization by HTLV-I and EBV. Adv Cancer Res 1991, 57:381-4II. 
25. Ueda S, Masutani H, Nakamura H, Tanaka T, Ueno M, Yodoi ]: Redox control of cell death. Antioxid Redox Signal 2002, 4:405-4I4.

26. Yoshioka J, Schreiter ER, Lee RT: Role of thioredoxin through interaction with signaling molecules. Antioxid Redox Signal 2006, 8:2|43-2|5|.

27. Saitoh M, Nishitoh H, Fujii M, Takeda K, Tobiume K, Sawada Y, Kawabata $\mathrm{M}$, Miyazono $\mathrm{K}$, Ichijo $\mathrm{H}$ : Mammalian thioredoxin is a direct inhibitor of apoptosis signal-regulating kinase (ASK) I. EMBO | 1998, I 7:2596-2606.

28. Pekkari K, Avila-Cariño J, Bengtsson A, Gurunath R, Scheynius A, Holmgren A: Truncated thioredoxin(Trx80) induces production of interleukin- 12 and enhances CDI 4 expression in human monocytes. Blood 200I, 97:3184-3190.

29. Kong KA, Jang JY, Lee CE: Identification of DC2I as a novel target gene counter-regulated by IL-4 and IL-I2. J Biochem Mol Biol 2002, 35:623-628

30. Jang JY, Lee CE: Mitochondrial adenine nucleotide translocase 3 is regulated by IL-4 and IFN- $\gamma$ via STAT-dependent pathways. Cell Immunol 2003, 226: I I-I9.

31. Wollman EE, d'Auriol L, Rimsky L, Shaw A, Jacquot JP, Wingfield P, Graber P, Dessarps F, Robin P, Galibert F: Cloning and expression of a cDNA for human thioredoxin. J Biol Chem 1988 263: $15506-15512$

32. Kang MW, Jang JY, Choi JY, Kim SH, Oh J, Cho BS, Lee CE: Induction of IFN-gamma gene expression by thioredoxin: positive feed-back regulation of ThI response by thioredoxin and IFN-gamma. Cell Physiol Biochem 2008, 2 I:2I 5-224.

33. Sahaf B, Soderberg A, Spyrou G, Barral AM, Pekkari K, Holmgren A, Rosen $A$ : Thioredoxin expression and localization in human cell lines: Detection of full-length and truncated species. Exp Cell Res 1997, 236:181-192.

34. Gupta JW, Kubin M, Hartman L, Castella M, Trinchieri G: Induction of expression of genes encoding components of the repiratory burst oxidase during differentiation of human myeloid cell lines induced by tumor necrosis factor and gamma interferon. Cancer Res 1992, 52:2530-2537.

35. Darnell JE, Kerr IM, Stark GR: Jak-Stat pathways and transcriptional activation in response to IFNs and other extracellular signaling proteins. Science $1994,264:|4| 5-|42|$

36. Nakamura $\mathrm{H}$, Nakamura $\mathrm{K}$, Yodoi J: Redox regulation of cellular activation. Annu Rev Immunol 1997, I 5:35 I-369.

37. Ferret PJ, Soum E, Negre O, Wollman EE, Fradelizi D: Protective effect of thioredoxin upon NO-mediated cell injury in THP I monocytic human cells. Biochem J 2000, 346:759-765.

38. Murata Y, Amao M, Yoneda J, Hamuro J: Intracellular thiol redox status of macrophages directs the ThI skewing in thioredoxin transgenic mice during aging. Mol Immunol 200I, 38:747-757.

39. King MR, Ismail AS, Davis LS, Karp DR: Oxidative stress promotes polarization of $\mathbf{T}$ cell differentiation toward a $\mathbf{T}$ helper $\mathbf{2}$ phenotype. J Immunol 2006, I 76:2765-2772.

40. Frossi B, Decardi M, Denaile KC, Rivera J, Puccilo C: Oxidative stress stimulates IL-4 and IL-6 production in mast cells by an APE/Ref-I-dependent pathways. Eur I Immunol 2003. 33:2168-2 177

4I. Kaghad M, Dessarps F, Jacquemin-Sablon $H$, Caput D, Fradelizi D, Wollman EE: Genomic cloning of human thioredoxin-encod ing gene: mapping of the transcription start point and analysis of the promoter. Gene 1994, 140:273-278.

42. Tonissen KF, Wells JR: Isolation and characterization of human thioredoxin-containing genes. Gene |99|, I02:22|-228.

43. Blanchette J, Pouliot $P$, Olivier M: Role of protein tyrosine phosphatases in the regulation of interferon-\{gamma\}-induced macrophage nitric oxide generation: implication of ERK pathway and AP-I activation. J Leukoc Biol 2007, 8 I:835-844.

44. Koul D, Shen R, Shishodia S, Takada Y, Bhat KP, Reddy SA, Aggarwal BB, Yung WK: PTEN down regulates AP-I and targets c-fos in human glioma cells via PI3-kinase/Akt pathway. Mol Cell Biochem 2007, 300:77-87.

45. Tanito M, Agbaga MP, Anserson RE: Upregulation of thioredoxin system via Nrf2-antioxidant responsive element pathway in adaptive-retinal neuroprotection in vivo and in vitro. Free Radic Biol Med 2007, 42:1838-1850.

46. Kim YC, Masutani H, Yamaguchi Y, Itoh K, Yamamoto M, Yodoi J: Hemin-induced activation of the thioredoxin gene by Nrf2. A differential regulation of the antioxidant responsive element by a switch of its binding factors. I Biol Chem 200I, 276: 18399-18406.

47. Powis G, Kirkpatrick DL, Angulo M, Baker A: Thioredoxin redox control of cell growth and death and the effects of inhibitors. Chem Biol Interact 1998, I I 2:23-34.

48. Powis G, Montfort WR: Properties and biological activities of thioredoxins. Annu Rev Pharmacol Toxicol 200I, 4I:26I-295.

49. Cerutti PA: Prooxidant states and tumor promotion. Science 1985, 227:375-38|

50. Tanaka T, Nakamura H, Nishiyama A, Hosoi F, Masutani H, Wada H, Yodoi J: Redox regulation by thioredoxin superfamily; protection against oxidative stress and aging. Free Radic Res 2000 33:851-855

5I. Mach B, Steimle V, Martinez-Soria E, Reith W: Regulation of MHC class II genes: lessons from a disease. Annu Rev Immunol I996, |4:30|-33|

52. Lah TT, Hawley M, Rock KL, Goldberg AL: Gamma-interferon causes a selective induction of the lysosomal proteases, cathepsins $B$ and $L$, in macrophages. FEBS Lett 1995, 363:85-89.

53. Cassatella MA, Bazzoni F, Flynn RM, Dusi S, Trinchieri G, Rossi F: Molecular basis of interferon-gamma and lipopolysaccharide enhancement of phagocyte respiratory burst capability. Studies on the gene expression of several NADPH oxidase components. J Biol Chem 1990, 265:2024l-20246.

54. Newburger PE, Ezekowitz RA, Whitney C, Wright J, Orkin SH: Induction of phagocyte cytochrome b heavy chain gene expression by interferon gamma. Proc Natl Acad Sci USA I988, 85:5215-5219.

55. Kawano S, Tatsumi E, Yoneda N, Yamaguchi N: Suppression of myeloperoxidase gene expression by gamma-interferon. Hum Cell 1992, 5:282-286.

56. Harris CA, Derbin KS, Hunte-McDonough B, Krauss MR, Chen KT, Smith DM, Epstein LB: Manganese superoxide dismutase is induced by IFN-gamma in multiple cell types: Synergistic induction by IFN-gamma and tumor necrosis factor or IL-I. J Immunol I99I, I47:I49-I54.

57. Arunachalam B, Phan UT, Geuze HT, Cresswell P: Enzymatic reduction of disulfide bonds in lysosomes: Characterization of a gamma-interferon-inducible lysosomal thiol reductase (GILT). Proc Natl Acad Sci USA 2000, 97:745-750.

58. Phan UT, Arunachalam B, Cresswell P: Gamma-interferon-inducible lysosomal thiol reductase (GILT): Maturation, activity, and mechanism of action. I Biol Chem 2000, 275:25907-259|4

59. Tanaka T, Hosoi F, Yamaguchi-Iwai Y, Nakamura H, Musutani H, Ueda $\mathrm{S}$, Yodoi J: Thioredoxin-2 (TRX-2) is an essential gene regulating mitochondria-dependent apoptosis. EMBO J 2002 , 2 I: I695-1703.

60. Jeong W, Yoon HW, Lee SR, Rhee SG: Identification and characterization of TRP I4, a thioredoxin-related protein of I4 kDa. New insights into the specificity of thioredoxin function. J Bio Chem 2004, 279:3|42-3150.

6I. Pekkari K, Gurunath R, Arner ESJ, Holmgren A: Truncated thioredoxin is a mitogenic cytokine for resting human peripheral blood mononuclear cells and is present in human plasma. J Biol Chem 2000, 275:37474-37480.

62. Sahaf B, Rosen A: Secretion of I0-kDa and I2-kDa thioredoxin species from blood monocytes and transformed leukocytes. Antioxid Redox Signal 2000, 2:717-726.

63. Bertini R, Howard OM, Dong HF, Oppenheim J, Bizzarri C, Sergi R, Caselli G, Pagliei S, Romines B, Wilshire JA, Mengozzi M, Nakamura H, Yodoi J, Pekkari K, Gurunath R, Holmgren A, Hezenberg LA Ghezzi P: Thioredoxin, a redox enzyme released in infection and inflammation, is a unique chemoattractant for neutrophils, monocytes, and $\mathbf{T}$ cells. I Exp Med 1999, 189:1783-1789.

64. Pekkari K, Avila-Cariño J, Grunath R, Bengtsson A, Scheynius A, Holmgren A: Truncated thioredoxin (Trx80) exerts unique mitogenic cytokine effects via a mechanism independent of thiol oxido-reductase activity. FEBS Lett 2003, 539:|43-| 48.

65. Yosida S, Katoh T, Tetsuka T, Uno K, Matsui N, Okamoto $\mathrm{T}$ : Involvement of thioredoxin in rheumatoid arthritis: its costimulatory roles in the TNF-alpha-induced production of IL6 and IL-8 from cultured synovial fibroblasts. J Immunol I999, 163:351-358. 
66. Rho HS, Park SS, Lee CE: Gamma irradiation up-regulates B cell differentiation antigen CD23 in human B cells by NF- $\kappa B$ activation. J Biochem Mol Biol 2004, 37:507-5 I4.

67. Jang JY, Lee CE: IL-4-induced up-regulation of adenine nucleotide translocase 3 and its role in Th cell survival from apoptosis. Cell Immunol 2006, 24I:I4-25.

68. So EY, Oh J, Jang JY, Kim JH, Lee CE: Ras/Erk pathway positively regulates Jak I/Stat 6 activity and IL-4 gene expression in Jurkat T cells. Mol Immunol 2007, 44:34I6-3426.

Publish with Bio Med Central and every scientist can read your work free of charge

"BioMed Central will be the most significant development for disseminating the results of biomedical research in our lifetime. "

Sir Paul Nurse, Cancer Research UK

Your research papers will be:

- available free of charge to the entire biomedical community

- peer reviewed and published immediately upon acceptance

- cited in PubMed and archived on PubMed Central

- yours - you keep the copyright

Submit your manuscript here:

http://www.biomedcentral.com/info/publishing_adv.asp
BioMedcentral 